
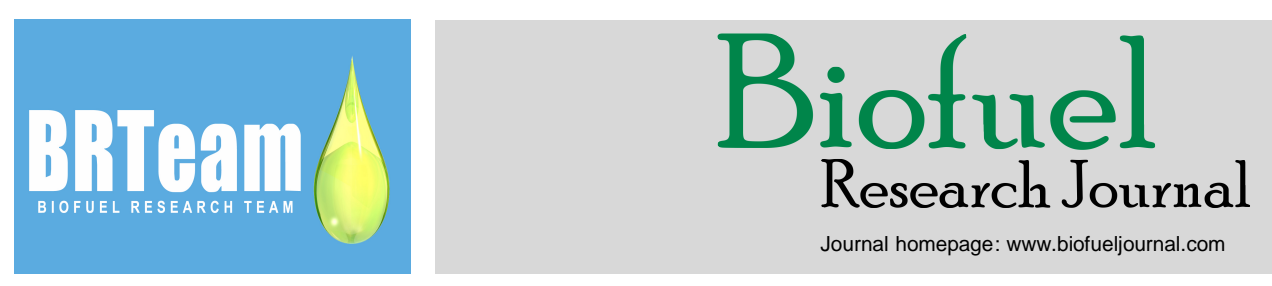

Original Research Paper

\title{
Microbial growth in Acrocomia aculeata pulp oil, Jatropha curcas oil, and their respective biodiesels under simulated storage conditions
}

Juciana Clarice Cazarolli ${ }^{1, *}$, Patrícia Dörr de Quadros $^{1}$, Francielle Bücker ${ }^{1}$, Mariana Ruiz Frazão Santiago ${ }^{2}$, Clarisse Maria Sartori Piatnicki ${ }^{3}$, Maria do Carmo Ruaro Peralba ${ }^{3}$, Eduardo Homem de Siqueira Cavalcanti ${ }^{2}$, Fátima Menezes Bento $^{1}$

\footnotetext{
${ }^{1}$ Department of Microbiology, Federal University of Rio Grande do Sul. Rua Sarmento Leite, $N^{\circ}$ 500, 90050-170, Porto Alegre, RS, Brazil.

${ }^{2}$ Corrosion and Degradation Division, National Institute of Technology, Av. Venezuela, $N^{o}$ 82, Sala 608, 200081-312, Rio de Janeiro, RJ, Brazil.

${ }^{3}$ Department of Inorganic Chemistry, Federal University of Rio Grande do Sul. Av. Bento Gonçalves, No 9500, 91501-970, Porto Alegre, RS, Brazil.
}

\section{HIGHLIGHTS} \begin{tabular}{l}
\hline Microbial growth capacity of filamentous fungi in \\
Acrocomia aculeata pulp oil and Jatropha curcas oil \\
and their respective biodiesels investigated. \\
$>$ Order of susceptibility to microbial growth was $A$. \\
aculeata pulp Biodiesel $>J$. curcas Biodiesel $>A$. \\
aculeata pulp oil $>J$. curcas oil. \\
$>$ Esters contents of A. aculeata pulp and J. curcas \\
biodiesels decreased by approx. 8 and $12 \%$ when \\
inoculated by fungi. \\
$>$ The occurrence of biodiesel biodegradation even \\
during a relatively short storage period of only $30 \mathrm{~d}$ \\
was observed.
\end{tabular}

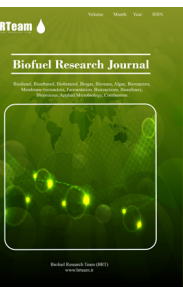




\section{Introduction}

Petroleum-based fuels have been the world's main energy source. Recently, concerns about the environment and the depletion of non-renewable sources have been driving research activities aiming at introducing sustainable alternatives. The use of various vegetable oil and fatty animal waste feedstocks as raw material for the production of biofuels, such as biodiesel, has been made possible through such efforts. According to the Brazilian Law $\mathrm{N}^{\mathrm{o}} 11.097$ / 2005, the addition of biodiesel to petroleum diesel in Brazil is mandatory, and currently this ratio stands at 7\% (B7) which has been predicted to increase to $10 \%$ by 2017 .

As mentioned earlier, different vegetable oils have been used as substrate for biodiesel production, but their production costs are still limiting the production process (Meneghetti et al., 2013). Thus, the use of alternative and less expensive fatty acids is encouraged. Nowadays, soybean is the most used crop for biodiesel production in Brazil. According to the National Agency of Petroleum (ANP), in 2014 more than $76 \%$ of 3.42 million cubic meters of biodiesel produced were derived from the Glycine $\max$ seed oil (ANP, 2015; Souza et al., 2015).

Among potential oilseeds to be used in biodiesel production are Pinhão Manso (Jatropha curcas) and Macaúba (AcrocomiA. aculeata). J. curcas, a drought-resistant plant, is a shrub belonging to the family Euphorbia which is cultivated in Central and South America, Southeast Asia, India, and Africa. $J$. curcas is grown in soils with low fertility and in climates considered unfavorable for most traditional food crops (Pandey et al., 2012). In addition to being perennial and easy growing, J. curcas has a high annual oil productivity of $2-4$ ton $\mathrm{ha}^{-1}$, and therefore, it is considered as an attractive biodiesel feedstock (Mofijur et al., 2013).

Another potential feedstock to be used for biodiesel production is Macaúba (Acrocomia aculeata). It is an arborescent perennial palm native to tropical forests, which belongs to the Palmae family, whose fruits have great potentials for oil production. The mesocarp is rich in oil which is yellow in color due to the presence of carotenes, while the kernel oil is light yellow (Duarte et al., 2012). In Brazil, A. aculeata is mainly found in the southeast and northeast regions (Lorenzi, 2006; Amaral, 2007). Compared with soybean with an oil productivity of $400-800 \mathrm{~kg} \mathrm{ha}^{-1}$ on average, oil production capacity of Macaúba is much higher, reaching up to $6600 \mathrm{~kg} \mathrm{ha}^{-1}$ which is considered the highest productivity among Brazilian palm trees. Thus, this plant is highly recommended as a potential oleaginous feedstock for biofuel production in Brazil (Lorenzi, 2006)

The predominant technology used for biodiesel production is based on transesterification reactions. The quality of the resultant product obtained through this process is highly dependent on the raw materials used and their intrinsic chemical features. Different feedstocks could lead to the generation of esters of different chemical properties, which could conseqently influence biodiesel degradability potentials (Teixeira et al., 2010; Kaushik et al., 2015). In fact, being composed of esters of fatty acids, biodiesel is more susceptible to degradation than diesel (Mariano et al., 2008). This may be considered as an advantage in scenarios where environmental contamination is of prominent concern. However, from the storage point of view, it can be considered as a disadvantage, since microbial degradation of biodiesel could significantly compromise the quality of the final product. Therefore, in line with the widespread search for alternative oilseeds as raw material for biodiesel production, it is also essential to explore the susceptibility of these biodiesel feedstock candidates to microbial growth during storage.

The aim of the present study was to evaluate the susceptibility of Acrocomia aculeata (Macaúba) pulp oil and Jatropha curcas oil, and their respective biodiesels to microbial contamination. More specifically, the physical and chemical characteristics in response to microbial contamination were investigated during a $30-d$ storage period.

\section{Materials and Methods}

\subsection{Oil and biodiesel samples}

A. aculeata pulp oil was produced by the Association of Small Rural Workers Riacho D'antas, Minas Gerais while J. curcas oil was obtained from the company Fabrica BRAZIL Ecoenergia. Biodiesels were produced by the National Institute of Technology (INT) using transesterification as production method according to Nascimento et al. (2016) and Silveira (2014).

\subsection{Microbial prospection}

In order to investigate the cultivable native microbiota of A. aculeata pulp oil and $J$. curcas oil, these oils were placed in contact with an aqueous phase consisting of the mineral nutrients (Bushnell and Haas, 1941). More specifically, $20 \mathrm{ml}$ of each oil sample was added into $20 \mathrm{ml}$ of the mineral minimum medium and the suspension was incubated for 15 $\mathrm{d}$ in a greenhouse at $30^{\circ} \mathrm{C}$. At sampling times of 0,7 , and $15 \mathrm{~d}, 100 \mu \mathrm{l}$ of the minimal mineral medium of each flask was taken and added to Petri dishes containing malt extract agar medium (for fungi isolation) and triptone soy agar medium (TSA: for bacteria isolation). Moreover, at the end of this experiment, i.e., day 15 , the biomass grown in the oil-water interface by the native population of the oils was filtered by using filter paper discs; weight 80, thickness $205 \mu \mathrm{m}$, and porosity $14 \mathrm{mM}$ (J. Prolab, Curitiba, Brazil), with the addition of hexane (Grade PA) as solvent to remove possible oil residues. Subsequently, the biomass was placed in a drying oven for $3 \mathrm{~d}$ and was then weighed on a precision scale.

\subsubsection{Isolation and identification of microorganisms}

After seeding by the aqueous phase, the culture plates were incubated at $30{ }^{\circ} \mathrm{C}$. On days 5 and 7 after cultivation, microbial isolation was performed. After obtaining pure cultures, only the identification of filamentous fungal cultures was performed. The DNA of the isolates were obtained by DNA extraction according to the method described by Grattapaglia and Ferreira (1996). Identification was performed by microculture followed by Sanger sequencing through targeting the ITS15.8S rRNA-ITS2 region for filamentous fungi using ITS-1 and ITS-4 primers (Covino et al., 2015). The amplicons were sequenced by automated Amersham Mega BACE 1000 sequencing system using the standard protocols of the Brazilian Genome Network. The sequences generated were blasted against to the GenBank database (available at http://blast.be-md.ncbi.nlm.nih.gov/).

2.3. Determination of the susceptibility of A. aculeata pulp oil, J. curcas oil, and their respective biodiesels to microbial contamination during a 30-d simulated storage period

A flowchart presenting the methodology developed in this work for assessing the susceptibility of A. aculeata pulp oil, J. curcas oil, and their respective biodiesels to microbial contamination is shown in Figure 1. The experiments were carried out in glass bottles containing $10 \mathrm{ml}$ of oil or biodiesel phase and $20 \mathrm{ml}$ of the mineral minimum medium (Bushnel and Haas, 1941) as the aqueous phase. The flasks were covered to prevent photo-oxidation. The experiments were performed in triplicate, assembled under destructive repetitions.

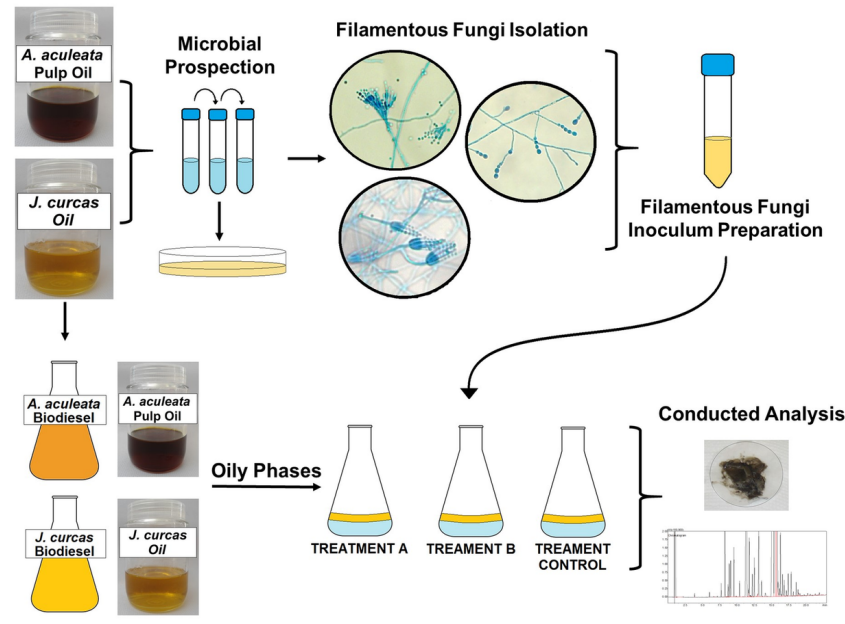

Fig.1. The flowchart presenting the methodology used to determine the susceptibility of $A$ aculeata pulp oil, J. curcas oil, and their respective biodiesels to microbial growth. 


\subsubsection{Microbial contamination of the samples}

The conditions evaluated in the present study included oil or biodiesel as RECEIVED (low contamination - Treatment A); oil or biodiesel inoculated with fungi (INOCULATED - Treatment B); and sterile oil or biodiesel (CONTROL). The inoculum was prepared using a consortium of the filamentous fungi isolated from the oils previously, i.e., two isolates of fungi obtained from J. curcas and 6 fungal isolates obtained from A. aculeata pulp oil samples. The spore suspensions of the fungi were prepared from 7-d old cultures on inclined malt extract agar. In order to facilitate spore dispersion, 2 $\mathrm{ml}$ of sterile saline $\left(\mathrm{NaCl} 8.5 \mathrm{gL}^{-1}\right)$ and $2 \mathrm{ml}$ of a surfactant (Tween 80 , prepared at a concentration of $0.01 \%$ ) were added to the tubes containing the fungal growth. The resultant solution was added to $10 \mathrm{ml}$ of the mineral medium in an Erlenmeyer flask and was kept under stirring at $120 \mathrm{rpm}$ at 30 ${ }^{\circ} \mathrm{C}$ for $24 \mathrm{~h}$. Counting of the spores of both inoculums was carried out in a Neubauer chamber to obtain a suspension containing of $10^{7}$ spores $\mathrm{mL}^{-1}$. An aliquot of this suspension was added to the flasks corresponding to Treatment $\mathrm{B}$ (with inoculum). All flasks were incubated at $30^{\circ} \mathrm{C}$ without stirring.

\subsubsection{Conducted analyses}

Sampling was conducted on $0,7,14,21$, and $30 \mathrm{~d}$ after incubation. At each sample time, the contents of the vials were added to a $250 \mathrm{ml}$ separation funnel, where the separation of the oil phase (A. aculeata pulp oil, J. curcas oil, and their respective biodiesels), aqueous phase (mineral minimal medium), and the biomass formed in oil-water interface was performed.

Subsequently, the analyses carried out on the aqueous phase at every sampling time included determination of $\mathrm{pH}$ and surface tension. To measure the surface tension, the aqueous phase was used in the absence of biomass. The surface tension values were determined on a digital surface tension meter (Gilbertini, Milan, Italy) using the Wilhelmy plate method. For this measurement, about $10 \mathrm{ml}$ of the aqueous phase were used. Liquid distilled water $\left(72.0 \mathrm{mN} \mathrm{m}^{-1}\right)$ and ethanol $\left(24.0 \mathrm{mN} \mathrm{m}^{-1}\right)$ were used as the standards for instrument calibration.

The biomass formed in the oil / water interface was also evaluated at each time after phase separation, when it was filtered in a vacuum system by using filter paper discs; weight 80, thickness $205 \mu \mathrm{m}$, and porosity $14 \mathrm{mM}$ (J. Prolab, Curitiba, Brazil), with the addition of hexane (Grade PA). After oven drying (to constant weight), the biomass was weighed on a precision balance.

At the sampling times of 0 and $30 \mathrm{~d}$, A. aculeata pulp oil, J. curcas oil, and their respective biodiesel samples were evaluated in terms of their constituent chemical structures using gas chromatography with a flame ionization detector (GC-FID) conducted in the Analytical Chemistry Laboratory of UFRGS, according to the EN 14103: 2011 method. The acid value of the oil and biodiesel samples was also determined according to the ABNT NBR 14448 (2005) method.

\subsection{Statistical analysis}

The data related to the biomass, surface tension, and $\mathrm{pH}$ measurements were statistically analyzed using Statistica 10.0. The variance analysis and the Tukey's test were performed at $5 \%$ significance level to verify the differences among the treatments against time.

\section{Results and Discussion}

\subsection{Microbial prospection}

The isolation of cultivable native microbiota was performed from both oil samples and the microorganisms isolated were divided according to their taxonomic group,i.e., fungi or bacteria. Overall, a total of 23 and 13 bacteria were isolated from the A. aculeata pulp oil and the $J$. curcas oil, respectively. The isolated filamentous fungi from J. curcas oil included Monascus ruber and Penicillium chrysogenum while Monascus ruber, Penicillium chermesinum, Monascus pilosus, Pestalotiopsis vismiae, Penicillium rubens, and Penicillium chrysogenum were isolated from the A. aculeata pulp oil.

\subsection{Susceptibility to microbial contamination}

\subsubsection{Microbial growth}

A. aculeata pulp oil and $J$. curcas oil as candidates for biodiesel production have been well explored by the previous studies (Raspe et al. 2014; Souza et al., 2016), but little has been reported on how their stability under storage condition is affected by microbial growth. It should be mentioned that some other biodiesel feedstocks such as soybean oil, olive oil, linseed oil, and beef tallow have been investigated in terms of their susceptibility to microbial contamination during storage (Cazarolli et al., 2012; Cazarolli et al., 2014; Soriano et al., 2015). However, based on their physicochemical properties, the biodiesel produced may have different characteristics which can directly influence the degradation reactions of abiotic or biotic nature during storage (Ramos et al., 2009). In line with this, the susceptibility of A. aculeata pulp oil, J. curcas oil, and their respective biodiesels to microbial contamination during simulated storage period is reported herein for the first time.

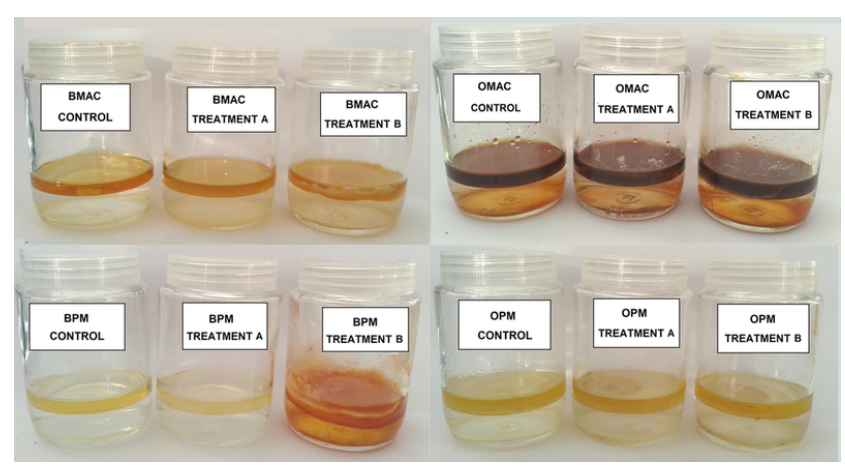

Fig.2. The appearance of the bottles used in the experiment after $30 \mathrm{~d}$ of incubation (Captions: BMAC: A. aculeata pulp Biodiesel; BPM: J. curcas Biodiesel; OMAC: A aculeata pulp oil; OPM: J. curcas oil; A: condition as received; B: inoculated with fungi, and CTE: sterile condition, control).

During the 30 days of growth, it was observed that all carbon sources (oils and biodiesels) well supported the growth of the microorganisms in all studied treatments. The values and characteristics of the total biomass formed in the oil / water interfaces (Fig. 2) are shown in Table 1. More biomass was generally formed in Treatment B; more specifically, in the samples containing A. aculeata pulp and J. curcas biodiesels $(315.0 \pm 5.1$ and $235.3 \pm 5.3 \mathrm{mg}$, respectively), indicating that the microorganisms which use the oil for growth can also, in case of possible contaminations during the transesterification process, utilize biodiesel as a source of carbon.

It is worth highlighting that the survival and growth of microorganisms in oil and/or biodiesel is related to their metabolic competence in accessing the carbon present in the structure of these substrates. In fact, the presence of fatty acids and esters in the environment would favor the growth of a portion of the indigenous microbial community with different capabilities in biodegrading such compounds as a carbon source, while promoting co-metabolism which could result in the persistence of microorganisms (Pasqualino et al., 2006; Kostka et al., 2011; Cruz et al, 2014).

The results obtained herein showed that in Treatment A, which included only native microbiota, i.e., microorganisms naturally present in the samples, the highest biomass values were found in A. aculeata pulp and $J$. curcas oil samples $(128.3 \pm 9.4 \mathrm{mg}$ and $86.7 \pm 7.7 \mathrm{mg}$, respectively), indicating that the native microbiota has a substantial deteriogenic capacity using the oils as a carbon source. It should also be noted that a microbiota capable of developing at the expense of fatty acid esters might also be added to the oil feedstock or the resultant biodiesel during shipping and handling. 
Moreover, the results observed for biodiesel samples in Treatment A revealed that the transesterification process may have contributed to a reduction in the microbial population/growth of oil samples leading to lower microbial presence in biodiesel samples (Table 1). After the 30-d experiment, the final biomass values between biodiesels were not significantly different $(\mathrm{p}>0,05)$.

Table 1.

Comparison of different the oil and biodiesel samples in terms of $\mathrm{pH}$, surface tension, and total biomass formed in the oil-water interface after $30 \mathrm{~d}$ of incubation. In each column, values with the same superscript symbol are not statistically different by Tukey test ( $p>0.05)$.

\begin{tabular}{|c|c|c|c|c|}
\hline $\begin{array}{l}\text { Oil/biodiesel } \\
\text { sample }\end{array}$ & Treatment & pH * & $\begin{array}{l}\text { Surface Tension } \\
\left(\mathbf{m N ~ m}^{-1}\right)^{* *}\end{array}$ & $\begin{array}{l}\text { Total Dry } \\
\text { Weight (mg) }\end{array}$ \\
\hline \multirow{3}{*}{$\begin{array}{l}\text { Acrocomia aculeata } \\
\text { pulp Biodiesel }\end{array}$} & Control & $6,96 \pm 0,01^{\#}$ & $19,5 \pm 0,86^{\ddagger}$ & - \\
\hline & Treatment A & $6,25 \pm 0,69^{\#}$ & $21,2 \pm 0,60^{\ddagger}$ & $78,8 \pm 8,6^{\ddagger}$ \\
\hline & Treatment B & $5,76 \pm 0,15^{£}$ & $25,2 \pm 0,96^{£}$ & $315,0 \pm 5,1^{\mathrm{E}}$ \\
\hline \multirow{3}{*}{$\begin{array}{l}\text { Jatropha curcas } \\
\text { Biodiesel }\end{array}$} & Control & $6,92 \pm 0,01^{\#}$ & $25,6 \pm 0,79^{8}$ & - \\
\hline & Treatment A & $6,71 \pm 0,18^{8}$ & $24,7 \pm 0,52^{\S}$ & $71,0 \pm 4,9^{\ddagger}$ \\
\hline & Treatment B & $6,32 \pm 0,03^{\S}$ & $25,8 \pm 0,83^{8}$ & $235,3 \pm 5,3^{\bullet}$ \\
\hline \multirow{3}{*}{$\begin{array}{l}\text { Acrocomia aculeata } \\
\text { pulp Oil }\end{array}$} & Control & $5,94 \pm 0,04^{\bullet}$ & $23,9 \pm 1,00^{\bullet}$ & - \\
\hline & Treatment A & $5,88 \pm 0,01^{\text {• }}$ & $25,6 \pm 0,95^{\bullet}$ & $128,3 \pm 9,4^{\#}$ \\
\hline & Treatment B & $5,66 \pm 0,05^{\square}$ & $23,1 \pm 0,49^{\square}$ & $218,8 \pm 6,2^{\bullet}$ \\
\hline \multirow{3}{*}{ Jatropha curcas Oil } & Control & $6,78 \pm 0,12^{\boldsymbol{\nabla}}$ & $22,0 \pm 0,95^{\mathbf{V}}$ & - \\
\hline & Treatment A & $6,73 \pm 0,06^{\boldsymbol{\nabla}}$ & $22,2 \pm 0,41^{\boldsymbol{\nabla}}$ & $86,7 \pm 7,7^{\ddagger}$ \\
\hline & Treatment B & $6,71 \pm 0,04^{\boldsymbol{\nabla}}$ & $19,5 \pm 0,87^{\epsilon}$ & $98,8 \pm 6,6^{\ddagger}$ \\
\hline
\end{tabular}

* $\mathrm{pH}$ Initial value: 7.2

** The initial surface tension value of the mineral medium: $54.2 \mathrm{mN} \mathrm{m}^{-1}$

\subsection{2. $p H$ variations}

The $\mathrm{pH}$ values measured during the storage simulation period are shown in Table 1. As presented, in the growth assays using A. aculeata pulp biodiesel, a significant reduction in $\mathrm{pH}$ was only observed in Treatment $\mathrm{B}$, when compared with the initial $\mathrm{pH}$ value of the aqueous phase (i.e., 7.2) $(\mathrm{p}<0.05)$. In this treatment, a fungal inoculum was added, which was likely to have contributed to the observed results. No significant changes were observed in other treatments with A. aculeata pulp biodiesel as the oily phase ( $\mathrm{p}>0.05$ ).

In case of the $J$. curcas biodiesel, a significant decrease in $\mathrm{pH}$ was also observed in both Treatments A and B ( $\mathrm{p}<0.05)$, whereas the $\mathrm{pH}$ value of the control sample did not change significantly over the $30-d$ storage period ( $p>$ $0,05)$, suggesting that in this case the decrease in $\mathrm{pH}$ may be ascribed to the observed microbial growth. The $\mathrm{pH}$ values measured for the A. aculeata pulp oil were significantly reduced compared with the baseline value $(\mathrm{p}<0.05)$. Since reductions were observed in all treatments, it could be concluded that these could be related to the A. aculeata pulp oil itself.

During the microbial degradation of hydrocarbons various compounds are produced, including organic acids (Bento et al., 2005; Callaghan, 2013). The mineral minimum medium developed by Bushnell and Haas (1941), which includes phosphate in its formulation, is generally used as a nutrient source in biodiesel biodegradation experiments (Bücker et al., 2011; Cazarolli et al., 2014). Phosphate is a limiting factor to microbial growth while it is also considered as an important buffering agent, an effect which is advantageous for maintaining the action of certain enzymes. However, possible changes in $\mathrm{pH}$ may not be detected due to low production of acidic metabolites by the microorganisms under study. These changes might have been missed during the short incubation period used in the present investigation. Polar organic molecules that might have partitioned into the aqueous phase are also likely to have functioned as buffers. Overall, the changes in $\mathrm{pH}$ in the aqueous phase could indicate the production of metabolites of acidic nature in quantities sufficient to overcome the buffering capacity of the mineral minimum medium. Beside the metabolic products formed during the fungal development, a reduction in the $\mathrm{pH}$ as a result of the treatments performed could be related to cellular lysis, polymeric products, and production of organic acids (Bento et al., 2005; Goldberg et al., 2006). Thus, one could conclude that by prolonging the cultivation period and without any limitations on oxygen and nutrients, the fungal isolates used in this work could have produced more metabolites which could have in turn led to a greater reduction in $\mathrm{pH}$.

The surface tension values of the aqueous phase decreased shortly after $7 \mathrm{~d}(\mathrm{p}<0.05)$, and these values remained unchanged until the end of the incubation period. This reduction was also observed in the control treatment, indicating that it might have been caused by the nature of the carbon chains present in the oils and biodiesels. In fact, due to their chemical structure, which is similar to the structure of some types of surfactants, the compounds present in the samples (i.e., esters and fatty acids) can act as surfactants in the presence of water and reduce the surface tension (Bücker et al., 2011; Cazarolli et al., 2012). Cazarolli et al. (2014) confirmed the presence of long-chain fatty acid esters by chromatography in a mineral minimum medium used as the aqueous phase in their experiment with biodiesel. Their results showed that the biodiesel components could migrate into the aqueous phase of the experiment. This well explains the reductions observed herein in the surface tension both in the control as well as in the other treatments (Table 1).

In a study by Kaczorek et al. (2011), they isolated Pseudomonas stutzeri from soils contaminated with crude oil and incubated the isolated with diesel oil for $14 \mathrm{~d}$. After the incubation period, a degradation rate of $88 \%$ was observed in the treatment which received $120 \mathrm{mg}$ of surfactant, in contrast to the treatment where no surfactant was added (54\% degradation). In the present study, it was not possible to detect the production of surfactants by microorganisms but biodiesel may have had a surfactant effect on the mineral medium used. Considering the fact that biodiesel can perform a surfactant function which can spontaneously increase its bioavailability, it could be concluded that this attribute is a determining factor in its greater degradability when compared with diesel oil.

\subsubsection{Acid value variations}

The variations in acid values in response to prolonged storage and the treatments performed are shown in Table 2. Overall, the initial acid value of the oils $\left(\mathrm{T}_{0}\right)$ were considerably different from those reported in the literature for some other oil feedstocks. For instance, in a study aimed at biodiesel production from soybean oil, Cunha (2008) determined the acidity of the oil at $0.104 \mathrm{mg} \mathrm{KOH} \mathrm{g}^{-1}$. After the $30 \mathrm{~d}$ experiment $\left(\mathrm{T}_{30}\right)$, the acid values decreased for both oils with native microbiota (Treatment A). The results observed in biodiesel samples were statistically indistinguishable among the samples at the beginning and after the incubation period ( $p>0.05)$. It should also be noted that it was not possible to determine the acid values for all the samples and for all the treatments.

Table 2.

Acid value $\left(\mathrm{mg} \mathrm{KOH}^{-1}\right)$ of the oil and biodiesel samples at the beginning of the experiment $\left(\mathrm{T}_{0}\right)$ and after $30 \mathrm{~d}$ of incubation $\left(\mathrm{T}_{30}\right)$. In each row, values with the same superscript symbol are not statistically different by Tukey test $(\mathrm{p}>0.05)$.

\begin{tabular}{|c|c|c|c|c|}
\hline \multirow{2}{*}{$\begin{array}{l}\text { Oil/biodiesel } \\
\text { sample }\end{array}$} & \multirow{2}{*}{ 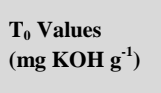 } & \multicolumn{3}{|c|}{$\mathrm{T}_{30}$ Values (mg KOH g $\left.\mathrm{g}^{-1}\right)$} \\
\hline & & Control & Treatment A & Treatment B \\
\hline $\begin{array}{l}\text { Acrocomia aculeata } \\
\text { pulp Biodiesel }\end{array}$ & $0.455 \pm 0.004^{\mathbf{}}{ }^{\nabla}$ & $0.316 \pm 0.14^{\boldsymbol{\nabla}+\boldsymbol{m}}$ & $0.354 \pm 0.16^{\mathbf{\nabla}}$ & $0.523 \pm 0.06^{\nabla}$ \\
\hline $\begin{array}{l}\text { Jatropha curcas } \\
\text { Biodiesel }\end{array}$ & $0.182 \pm 0.003^{\prime}$ & $0.360 \pm 0.09^{\boldsymbol{\nabla} \# \mathbf{m}}$ & $-{ }^{a}$ & $0.360 \pm 0.14^{\mathbf{\nabla} \neq \boldsymbol{\bullet}}$ \\
\hline $\begin{array}{l}\text { Acrocomia aculeata } \\
\text { pulp Oil }\end{array}$ & $2.582 \pm 0.062^{\bullet}$ & $0.375^{\mathrm{b} \ \neq \boldsymbol{\bullet}}$ & $-{ }^{a}$ & $0.275^{\mathrm{b} \neq \boldsymbol{m}}$ \\
\hline Jatropha curcas Oil & $11.375 \pm 0.019^{*}$ & $0.305 \pm 0.05^{\boldsymbol{\nabla} \# \mathbf{m}}$ & $0.225^{\mathrm{b}}$ & $-a^{a}$ \\
\hline
\end{tabular}

${ }^{a}$ Results were not conclusive; the turning point was not found.

${ }^{b}$ Results were not conclusive; the turning point was not found for all replicates. 
According to Silveira (2014), biodiesel properties such as kinematic viscosity, acidity, triglycerides, diglycerides and monoglycerides content, free and total glycerol contents, and ester content are dependent on the transesterification process. Other parameters such as oxidation stability, iodine index, carbon residue, and cold filter plugging point depend on the nature of the oil used for the production of biodiesel. The acid value refers to the amount of free fatty acids in a given sample and is linked to aging and degradation when stored. Furthermore, the possibility of corrosion is indicated as a result of high acid values (Shalaby, 2015). Raw materials with high acidity values require a pretreatment before transesterification with basic catalysts because they can affect the yield and reaction time as well as the results of the biodiesel purification step (Tiwari et al., 2007).

Silveira (2014) and Nascimento et al. (2016) also produced A. aculeata and $J$. curcas biodiesels in different studies using the alkaline transesterification method, respectively, and achieved $97.8 \%$ of esters for A. aculeata biodiesel and $98.5 \%$ of esters for J. curcas biodiesel. Accordingly, the J. curcas and A. aculeata pulp oils were found to have different characteristics, such as fatty acid composition and acidity index, and the alkaline transesterification reaction was found effective in framing the biodiesels with the standard parameters required by the Resolution $\mathrm{N}^{\circ} 14$ of the National Agency of petroleum, natural gas, and biofuels (ANP) (ANP, 2012; Silveira, 2014; Nascimento et al., 2016).

Table 3.

Ester contents of $J$. curcas Biodiesel at $\mathrm{T}_{0}$ and $\mathrm{T}_{30}$. In each column, values with the same superscript symbol are not statistically different by Tukey test ( $p>0.05$ ).

\begin{tabular}{|c|c|c|c|c|}
\hline \multirow{3}{*}{ Esters (\%) } & \multicolumn{4}{|c|}{ Jatropha curcas Biodiesel } \\
\hline & \multirow{2}{*}{$\mathbf{T}_{\mathbf{0}}$} & \multicolumn{3}{|c|}{$\mathbf{T}_{30}$} \\
\hline & & Control & Treatment A & Treatment B \\
\hline $\mathrm{C}_{12}$ & - & - & - & - \\
\hline $\mathrm{C}_{13}$ & - & - & - & - \\
\hline $\mathrm{C}_{14: 1}$ & - & - & - & - \\
\hline $\mathrm{C}_{16}$ & $0,04 \pm 0,00 *$ & $0,03 \pm 0,02 *$ & $0,00 \pm 0,00^{\#}$ & $0,00 \pm 0,00^{\#}$ \\
\hline $\mathrm{C}_{16: 1}$ & - & - & - & - \\
\hline $\mathrm{C}_{17}$ & - & - & - & - \\
\hline $\mathrm{C}_{18}$ & - & - & - & - \\
\hline $\mathrm{C}_{18: 1}$ & $13,46 \pm 0,03^{*}$ & $13,32 \pm 0,03 *$ & $13,88 \pm 6,25^{*}$ & $11,37 \pm 0,72 *$ \\
\hline $\mathrm{C}_{18: 2}$ & $0,65 \pm 0,00^{*}$ & $0,65 \pm 0,01 *$ & $0,66 \pm 0,30^{*}$ & $0,51 \pm 0,04 *$ \\
\hline $\mathrm{C}_{20}$ & $6,12 \pm 0,03^{*}$ & $5,80 \pm 0,04 *$ & $6,19 \pm 2,94 *$ & $6,33 \pm 0,14^{*}$ \\
\hline $\mathrm{C}_{20: 1}$ & $44,43 \pm 0,08 *$ & $44,37 \pm 0,10^{*}$ & $45,65 \pm 4,38 *$ & $45,03 \pm 0,29 *$ \\
\hline $\mathrm{C}_{18: 3}$ & $34,70 \pm 0,07 *$ & $34,68 \pm 0,17 *$ & $32,88 \pm 1,14^{*}$ & $35,62 \pm 0,47^{*}$ \\
\hline $\mathrm{C}_{22}$ & $0,25 \pm 0,08^{*}$ & $0,53 \pm 0,08^{*}$ & $0,50 \pm 0,28^{*}$ & $0,51 \pm 0,07 *$ \\
\hline $\mathrm{C}_{22: 1}$ & $0,19 \pm 0,00^{*}$ & $0,19 \pm 0,00^{*}$ & $0,20 \pm 0,09 *$ & $0,22 \pm 0,01^{*}$ \\
\hline $\mathrm{C}_{23}$ & $0,06 \pm 0,00^{*}$ & $0,06 \pm 0,00^{*}$ & $0,06 \pm 0,03^{*}$ & $0,06 \pm 0,00^{*}$ \\
\hline $\mathrm{C}_{24: 1}$ & $0,08 \pm 0,09^{*}$ & $0,350,08^{*}$ & $0,32 \pm 0,32 *$ & $0,35 \pm 0,07 *$ \\
\hline Esters Total & $95,77 \pm 0,17 *^{*}$ & $99,82 \pm 8,63^{*}$ & $98,78 \pm 6,85^{*}$ & $83,45 \pm 3,28^{\#}$ \\
\hline
\end{tabular}

\subsubsection{Biodiesel biodegradation}

The results obtained on the biodegradation of biodiesel samples during the storage period are tabulated in Tables 3 and 4 . According to the total esters values, none of the biodiesels met the requirements set by the Resolution $\mathrm{N}^{\circ}$ 14 of the ANP (ANP, 2012) even before they were subjected to biodeteriogenic activity. For $J$. curcas biodiesel, the total esters at $\mathrm{T}_{0}$ was close to the standard total esters limit of $96.5 \%$, but could still not be released for consumption. Similarly, based on the total esters value measured by gas chromatography analysis for A. aculeata pulp biodiesel, its commercialization would not be allowed according to Resolution $\mathrm{N}^{\circ} 14$ of the ANP (ANP, 2012).

Table 4.

Ester contents of A. aculeata pulp Biodiesel at $T_{0}$ and $T_{30}$. In each column, values with the same superscript symbol are not statistically different by Tukey test ( $\mathrm{p}>0.05)$.

\begin{tabular}{|c|c|c|c|c|}
\hline \multirow{3}{*}{ Esters (\%) } & \multicolumn{4}{|c|}{ Acrocomia aculeata pulp Biodiesel } \\
\hline & \multirow{2}{*}{$\mathbf{T}_{\mathbf{0}}$} & \multicolumn{3}{|c|}{$\mathbf{T}_{30}$} \\
\hline & & Control & Treatment A & Treatment B \\
\hline $\mathrm{C}_{12}$ & $0,14 \pm 0,00 *$ & $0,14 \pm 0,01 *$ & $0,17 \pm 0,02 *$ & $0,07 \pm 0,06^{\#}$ \\
\hline $\mathrm{C}_{13}$ & $0,27 \pm 0,01 *$ & $0,29 \pm 0,02 *$ & $0,32 \pm 0,04 *$ & $0,12 \pm 0.02^{\#}$ \\
\hline $\mathrm{C}_{14: 1}$ & $2,03 \pm 0,04 *$ & $2,09 \pm 0,15^{*}$ & $2,59 \pm 0,55^{*}$ & $1,82 \pm 0,17 *$ \\
\hline $\mathrm{C}_{16}$ & $1,77 \pm 0,03 * \#$ & $1,50 \pm 0,10^{*}$ & $2,28 \pm 0,50^{\#}$ & $1,81 \pm 0,09^{* *}$ \\
\hline $\mathrm{C}_{16: 1}$ & $0,14 \pm 0,00 *^{*}$ & $0,10 \pm 0,00^{*}$ & $0,17 \pm 0,04^{\#}$ & $0,13 \pm 0,01 *^{\#}$ \\
\hline $\mathrm{C}_{17}$ & $0,15 \pm 0,00^{*}$ & $0,11 \pm 0,01^{*}$ & $0,21 \pm 0,08^{*}$ & $0,16 \pm 0,00^{*}$ \\
\hline $\mathrm{C}_{18}$ & $0,23 \pm 0,01 *$ & $0,17 \pm 0,01^{\#}$ & $0,26 \pm 0,03 *$ & $0,25 \pm 0,01 *$ \\
\hline $\mathrm{C}_{18: 1}$ & $23,64 \pm 0,25^{*}$ & $24,53 \pm 1,59^{*}$ & $22,93 \pm 2,98 *$ & $23,23 \pm 0,65^{*}$ \\
\hline $\mathrm{C}_{18: 2}$ & $3,12 \pm 0,08 *$ & $2,88 \pm 0,41 *$ & $3,42 \pm 0,43 *$ & $3,30 \pm 0,24 *$ \\
\hline $\mathrm{C}_{20}$ & $9,92 \pm 0,14 *$ & $9,56 \pm 2,72 *$ & $12,70 \pm 1,70^{*}$ & $11,18 \pm 0,41^{*}$ \\
\hline $\mathrm{C}_{20: 1}$ & $52,40 \pm 0,50^{*}$ & $51,51 \pm 1,61 *$ & $49,90 \pm 1,23^{*}$ & $50,86 \pm 0,91 *$ \\
\hline $\mathrm{C}_{18: 3}$ & $4,42 \pm 0,07 *$ & $5,17 \pm 0,36^{*}$ & $2,42 \pm 1,98^{*}$ & $4,54 \pm 0,17 *$ \\
\hline $\mathrm{C}_{22}$ & $0,37 \pm 0,47^{*}$ & $0,95 \pm 0,03$ *\# & $1,42 \pm 0,34^{\# \&}$ & $1,97 \pm 0,08^{\&}$ \\
\hline $\mathrm{C}_{22: 1}$ & $0,27 \pm 0,02 *$ & $0,28 \pm 0,01 *$ & $0,37 \pm 0,11^{*}$ & $0,32 \pm 0,01 *$ \\
\hline $\mathrm{C}_{23}$ & $0,60 \pm 0,02 *$ & $0,66 \pm 0,04 *$ & $0,77 \pm 0,18 *$ & $0,00 \pm 0,00^{\#}$ \\
\hline $\mathrm{C}_{24: 1}$ & $0,51 \pm 0,44^{*}$ & $0,04 \pm 0,03^{*}$ & $0,04 \pm 0,03 *$ & $0,22 \pm 0,38^{*}$ \\
\hline Esters Total & $81,44 \pm 0,89^{*}$ & $81,38 \pm 2,17 *$ & $82,69 \pm 0,67 *$ & $73,90 \pm 2,98^{\#}$ \\
\hline
\end{tabular}

After the transesterification of the A. aculeata pulp oil in the present study, the esters percentages of methyl oleate (C18.1), methyl linoleate $(\mathrm{C} 18: 2)$, and methyl palmitate (C16) were different $(23.64 \pm 0,25 \%$; $3.12 \pm 0.08 \%$, and $1.77 \pm 0,03 \%$, respectively) from those reported by Amaral et al. (2011), who also analyzed the fatty acid composition of $A$ aculeata pulp oil (69.07\% for oleic acid (C18.1), 6,77\% for linoleic acid (C18.2), and $12.13 \%$ for palmitic acid (C16)). Similar observations indicating the predominance of the C18.1 esters have been reported by other studies conducted on A. aculeata pulp oil (Duarte et al., 2012; Melo, 2012). In the A. aculeata pulp biodiesel evaluated in this study, some esters of smaller chains (i.e., C12, C13, etc.) were also detected. The most predominant ester found in the sample, however, was the eicosenoate methyl ester (C20.1) $(52,40 \pm 0,50 \%)$, in contrast to the literature (Doná, 2012). Studies using the $J$. curcas oil as raw material found oleic and linoleic acids as the major constituents of the oil making up between 70$77 \%$ of the oil composition (Ribeiro et al., 2012). In the present study, the major esters produced from $J$. curcas oil were linolenate methyl ester (C18.3) and eicosenoate methyl ester (C20.1), totaling $75 \%$ of the samples' esters.

It should be noted that the oil content and fatty acid composition of oil seeds depend on the plant species and cooul be altered by their maturation time, the cultivar, and their growth conditions (Atabani et al., 2013, Schulte et al., 2013). The oil samples used for the production of biodiesel in the present investigation remained in storage prior to the study for four months at temperatures ranging from $26-28{ }^{\circ} \mathrm{C}$, which may have contributed to the differences observed in the esters content of these samples (Silveira, 2014).

The total value of the esters detected in Treatment B decreased significantly after $30 \mathrm{~d}$ for $J$. curcas biodiesel $(\mathrm{p}<0.05)$. A reduction of approximately $12 \pm 2.2 \%$ in the total ester content was observed compared 
with the content measured at the beginning of the experiment. No significant changes between the initial and ending time esters contents were detected for the Control treatment and biodiesel as received (Treatment A) ( $>0.05)$. These findings indicated that the fungi inoculum could be considered responsible for the reductions observed in the total esters contents. More specifically, in Treatment B, the J. curcas biodiesel promoted the second largest biomass formed, which was consistent with the total biodegradation percentage observed. When analyzing each ester individually, only palmitic ester showed a significant reduction, although in small percentages $(p<0,05)$. For A. aculeata pulp biodiesel, total esters percentage showed a reduction of $8 \pm 2.1 \%$ after $30 \mathrm{~d}$ in Treatment B. Moreover, a statistically-significant reduction was observed in the contents of the esters with lower carbon chains (C12 to C13), minor constituents of the sample though $(\mathrm{p}<0.05)$. The impurities (non-esters components) of the A. aculeata pulp and $J$. curcas biodiesels investigated herein stood at $18,55 \pm 0,88 \%$ and $4,15 \pm 0,15 \%$ of, respectively. Therefore, it could be concluded that these impurities, such as glycerol, or mono, di- and triacylglycerides (resulted from low transesterification yield and/or a poor purification process), might have been consumed by fungi and thus could have contributed to the increased susceptibility of biodiesel to microbial contamination (Bücker et al., 2011; Cazarolli et al., 2014).

Vieira et al. (2006) observed the degradation of palm oil by an unidentified microbial isolate and obtained the following degradation profile of methyl esters; myristic acid by $31.67 \%$, palmitic acid by $51.28 \%$, stearic acid by $34.11 \%$, oleic acid by $33.31 \%$, and linoleic acid by $25.16 \%$. These results suggested a bacterial specificity for different methyl esters constituents of palm oil biodiesel. On the contrary, in the present work, it was not possible to observe such degradation ratios for each ester, confirming that other biofuel elements may have been consumed, or the time of incubation experiment was too short to observe such results.

After the $30 \mathrm{~d}$ experiment, the highest microbial biomass was obtained in both oil samples in Treatment A. This suggested that the carbon source present as fatty acids and other oil components were more easily assimilated by the native microbiota, including the non-cultivable microorganisms.

It has been reported that several processes including oxidation under aerobic conditions, thermal decomposition by excessive heat, as well as contaminations and impurities can modify fuels properties, significantly decreasing their stability and, therefore, their durability during storage (Yaakob et al., 2014). Furthermore, when water is present in storage systems, hydrolysis reactions may also occur, resulting in the release of free fatty acids, which in turn increases the acidity leading to the instability of biodiesel (Vieira et al., 2006).

It should also be noted that oil feedstocks with high acidity values which also have high unsaturation degrees are less stable during storage periods, and therefore, would be more susceptible to oxidative reactions induced chemically or biologically (Pullen and Saeed, 2012). In the present work, the A. aculeata pulp biodiesel had a higher percentage of saturated fatty acid esters compared with $J$. curcas biodiesel ( $13.45 \%$ vs. $6.47 \%$, respectively), and this could explain the difference observed in the biodegradation rates ( $8 \pm 2.1 \%$ vs. $12 \pm 2.2 \%$, respectively).

Several vegetable oil feedstocks, extremely adapted to the Brazilian climate and soil, have been considered for biodiesel production in Brazil including palm oil, coconut oil, Orbignya sp., peanut, canola, turnip, $J$. curcas, A. aculeata, and almonds. As previously mentioned, diversification of raw materials could make the production process less onerous and could further encourage the use of biofuels such as biodiesel. Among these resources, A. aculeata pulp oil and J. curcas oil, due to their desirable characteristics suitable for biodiesel production, are of great importance. Moreover, when compared with the other oleaginous, these plants have high productivities and high oil yields, and the production of biodiesel from them is already well established (Nascimento et al., 2014; Cesar et al., 2015). Nevertheless. studies on the chemical and biological stability of the biodiesel produced during storage were scarce and to the best of our knowledge, this was the first report shedding light on the storage stability of these oil feedstocks and their respective biodiesels. Future investigations are required to further compare the stability of these oil feedstocks with the other resources such as soybean oil and beef tallow, the major constituents of biodiesel production in Brazil today.

\section{Conclusions}

The $J$. curcas and A. aculeata pulp oil samples were evaluated for their cultivable microbial populations. According to the fungal growth results, the stored oils and biodiesels were potentially susceptible to microbial degradation. At the end of 30 days of simulated storage, the biomass formed $(\mathrm{mg})$ in the samples indicated a predisposition order to microbial growth under the conditions of this study as follows: A. aculeata pulp biodiesel> J. curcas biodiesel> A. aculeata pulp Oil> J. curcas Oil. When A. aculeata pulp biodiesel was inoculated with the fungal consortium, the biomass formed was measured at $315 \pm 5.1 \mathrm{mg}$ and a $8 \pm 2.1 \%$ reduction in the total esters was observed. Moreover, J. curcas biodiesel showed a $12 \pm 2.2 \%$ degradation in total esters in response to the fungal inoculation where a considerable microbial biomass was formed $(235.3 \pm 5.3 \mathrm{mg})$ The results obtained herein revealed that the investigated biodiesels deteriorated during storage in the presence of microbial communities even over the short period of $30 \mathrm{~d}$. Longer test times at pilot scale could help to better understand the susceptibility of these biodiesel feedstock candidates and to develop microbial growth control methods in order to increase their shelf life during storage.

\section{Acknowledgements}

The authors would like to thank LAB-BIO/UFRGS, CECOM/UFRGS, INT (CNPq Grant $\mathrm{N}^{\circ}$ 558896/2010-3), and CNPq (Process N 381691/2013-6) for the funds provided during the course of this study.

\section{References}

[1] ABNT NBR 14448, 2005. Available at http://www.abntcatalogo.com.br (accessed on 11 November 2016).

[2] Amaral, F.P.D., Broetto, F., Batistela, C.B., Jorge, S.M.A. 2011. Extração e caracterização qualitativa do óleo da polpa e amêndoas de frutos de macaúba [Acrocomia aculeata (Jacq) Lodd. ex Mart] coletada na região de Botucatu-SP. Energia na Agricultura. $12-20$.

[3] Amaral, F.P., 2007. Study of physico-chemical characteristics of almond oil and macaúba pulp [Acrocomia aculeata (Jacq.) Lodd. ex Mart]. Master of Science Dissertation, Faculdade de Ciências Agronômicas da Unesp, Brasil.

[4] ANP Resolutions, National Agency of Petroleum, 2012. Available a http://www.anp.gov.br (accessed on 11 November 2016).

[5] ANP, National Agency of Petroleum, Statistical Yearbook, 2015 Available at http://www.anp.gov.br (accessed on 11 November 2016).

[6] Atabani, A.E., Silitonga, A.S., Ong, H.C., Mahlia, T.M.I., Masjuki, H.H., Badruddin, I.A., Fayaz, H., 2013. Non-edible vegetable oils: a critical evaluation of oil extraction, fatty acid compositions, biodiesel production, characteristics, engine performance and emissions production. Renew. Sust. Energy Rev.18, 211-245.

[7] Bento, F.M., Beech, I.B., Gaylarde, C.C., Englert, G.E., Muller, I.L., 2005. Degradation and corrosive activities of fungi in a diesel-mild steel-aqueous system. World J. Microbiol. Biotechnol. 21(2), 135 142.

[8] Bücker, F., Santestevan, N.A., Roesch, L.F., Jacques, R.J.S., Peralba, M.D.C.R., Camargo, F.A., Bento, F.M., 2011. Impact of biodiesel on biodeterioration of stored Brazilian diesel oil. Int Biodeterior. Biodegrad. 65(1), 172-178

[9] Bushnell, L. D., Haas, H. F., 1941. The utilization of certain hydrocarbons by microorganisms. J. Bacteriol. 41, 653-673.

[10] Callaghan, A.V., 2013. Metabolomic investigations of anaerobic hydrocarbon-impacted environments. Curr. Opin. Biotechnol. 24(3), 506-515.

[11] Cazarolli, J.C., Bücker, F., Manique, M.C., Krause, L.C., Maciel, G.P.D.S., Onorevoli, B., Caramão, E.B., Cavalcanti, E.H.D.S., Samios, D., Peralba, M.D.C.R., Bento, F.M., 2012. Suscetibilidade do biodiesel de sebo bovino à biodegradação por Pseudallescheria boydii. Rev. Bras. de Bioc. 10(3), 251-257.

[12] Cazarolli, J.C., Guzatto, R., Samios, D., Peralba, M.D.C.R., Cavalcanti, E.H.D.S., Bento, F.M., 2014. Susceptibility of linseed, 
soybean, and olive biodiesel to growth of the deteriogenic fungus Pseudallescheria boydii. Int. Biodeterior. Biodegrad. 95, 364-372.

[13] da Silva César, A., de Azedias Almeida, F., de Souza, R.P., Silva, G.C., Atabani, A.E., 2015. The prospects of using Acrocomia aculeata (macaúba) a non-edible biodiesel feedstock in Brazil. Renew. Sust. Energy Reviews. 49, 1213-1220.

[14] Covino, S., D'Annibale, A., Stazi, S.R., Cajthaml, T., Čvančarová, M., Stella, T., Petruccioli, M., 2015. Assessment of degradation potential of aliphatic hydrocarbons by autochthonous filamentous fungi from a historically polluted clay soil. Sci. Total Environ. 505, 545-554.

[15] Cruz, J.M., Tamada, I.S., Lopes, P.R.M., Montagnolli, R.N., Bidoia, E.D., 2014. Biodegradation and phytotoxicity of biodiesel, diesel, and petroleum in soil. Water Air Soil Pollut. 225(5), 1-9

[16] Cunha, E. M., 2008. Characterization of biodiesel produced from mixtures of raw materials: bovine tallow, chicken oil and soybean oil. Master of Science Dissertation, Universidade Federal do Rio Grande do Sul - UFRGS, Brasil.

[17] Doná, G., 2012. Production of methyl esters with ethyl acetate supercritical tubular reactor. Master of Science Dissertation, Universidade Federal do Paraná, Brasil.

[18] Duarte, I. D., Rogério, J. B., Licurgo, F. M. S., Back, G. R., Santos, M. C. S., Antoniassi, R., Faria-Machado, A. F., Bizzo, H. R., Junqueira, N. T. V., 2012. Efeito da maturação de frutos de macaúba no rendimento de óleo e na composição em ácidos graxos. Resumos do $5^{\circ}$ Congresso da Rede Brasileira de Tecnologia de Biodiesel e $8^{\circ}$ Congresso Brasileiro de Plantas Oleaginosas, Óleos, Gorduras e Biodiesel, Salvador, Brasil, 1, 253-254

[19] Ferreira, M.E., Grattapaglia, D., 1996. Introdução ao uso de marcadores moleculares em análise genética. EMBRAPA-CENARGEN.

[20] Goldberg, I., Rokem, J.S., Pines, O., 2006. Organic acids: old metabolites, new themes. J. Chem. Technol. Biotechnol. 81(10), 1601 1611 .

[21] Kaczorek, E., Olszanowski, A., 2011. Uptake of hydrocarbon by Pseudomonas fluorescens (P1) and Pseudomonas putida (K1) strains in the presence of surfactants: a cell surface modification. Water Air Soil Pollut. 214(1), 451-459.

[22] Kaushik, S., Kumar, M., Thakur, S., Chhabra, M., Aggarwal, K.M., Tyagi, R.K., 2015. Biodiesel production and its performance characteristics measurement: a review and analysis. J. Chem. Pharm. Res. 7(5), 1075-1082.

[23] Kostka, J.E., Prakash, O., Overholt, W.A., Green, S.J., Freyer, G., Canion, A., Delgardio, J., Norton, N., Hazen, T.C., Huettel, M., 2011. Hydrocarbon-degrading bacteria and the bacterial community response in gulf of mexico beach sands impacted by the deepwater horizon oil spill. Appl. Environ. Microbiol. 77(22), 7962-7974.

[24] Lorenzi, G.M.A.C., 2006. Acrocomia aculeata (Jacq.) Lodd. Mart. exArecaceae: foundations for sustainable harvesting. Doctoral thesis, Universidade Federal do Paraná, Brasil.

[25] Mariano, A.P., Tomasella, R.C., Oliveira, L.M., Contiero, J., Angelis, D.F., 2008. Biodegradability of diesel and biodiesel blends. Afr. J. Biotechnol. 7(9). 1323-1328.

[26] Melo, P.G., 2012. Production and characterization of biodiesel obtained from the oilseed Macaúba (Acrocomia aculeata). Doctoral thesis, Universidade Federal de Uberlândia, Brasil

[27] Meneghetti, S.M.P., Meneghetti, M.R., Brito, Y.C., 2013. A Reação de Transesterificação, Algumas Aplicações e Obtenção de Biodiesel. Rev. Virt. Quím. 5(1), 63-73.

[28] Mofijur, M., Masjuki, H.H., Kalam, M.A., Atabani, A.E., 2013. Evaluation of biodiesel blending, engine performance and emissions characteristics of Jatropha curcas methyl ester: Malaysian perspective. Energy. 55, 879-887

[29] Nascimento, M. R. F., 2014. Production and shelf life of biodiesel from Pinhão Manso oil (Jatropha curcas) obtained by esterification followed transesterification. Masters Dissertation, Universidade Federal do Rio de Janeiro, Brasil.

[30] Pandey, V.C., Singh, K., Singh, J.S., Kumar, A., Singh, B., Singh, R.P., 2012. Jatropha curcas: A potential biofuel plant for sustainable environmental development. Renew. Sust. Energy Rev. 16(5), 2870 2883
[31] Pasqualino, J.C., Montane, D., Salvado, J., 2006. Synergic effects of biodiesel in the biodegradability of fossil-derived fuels. Biomass Bioenergy. 30(10), 874-879.

[32] Pullen, J., Saeed, K., 2012. An overview of biodiesel oxidation stability. Renew. Sust. Energy Rev. 16(8), 5924-5950.

[33] Ramos, M.J., Fernández, C.M., Casas, A., Rodríguez, L., Pérez, Á. 2009. Influence of fatty acid composition of raw materials on biodiesel properties. Bioresour. Technol. 100(1), 261-268.

[34] Raspe, D., Mello, B., Silva, P.J., da Silva, C., 2014. Esterificação Homogênea dos ácidos graxos livres do óleo da polpa de Macaúba (Acrocomia aculeata). E-xacta. 7(1), 45-54.

[35] Ribeiro, R. A., Queiroz, M. G. M. N., Alves, V. L., Starling, M. F. R., Cardoso, C. A., 2012. Perfil de ácidos graxos de óleo bruto de pinhão-manso (Jartropha curcas) submetido ao armazenamento. Resumos do $5^{\circ}$ Congresso da Rede Brasileira de Tecnologia de Biodiesel e $8^{\circ}$ Congresso Brasileiro de Plantas Oleaginosas, Óleos Gorduras e Biodiesel, Salvador, Brasil. 305-306.

[36] Schulte, L.R., Ballard, T., Samarakoon, T., Yao, L., Vadlani, P., Staggenborg, S., Rezac, M., 2013. Increased growing temperature reduces content of polyunsaturated fatty acids in four oilseed crops. Ind. Crops Prod. 51, 212-219.

[37] Shalaby, E.A., 2015. A review of selected non-edible biomass sources as feedstock for biodiesel production. Biofuels - Status and Perspective, InTech, pp. 3-20.

[38] Silveira, S.D., 2014. Production of Biodiesel from Macaúba oi (Acrocomia aculeata) via esterification followed methy transesterification with basic catalyst. Master of Science Dissertation, Universidade Federal do Rio de Janeiro, Brasil.

[39] Soriano, A.U., Martins, L.F., de Assumpção Ventura, E.S., de Landa, F.H.T.G., de Araújo Valoni, É., Faria, F.R.D., Ferreira, R.F., Faller, M.C.K., Valério, R.R., de Assis Leite, D.C., do Carmo, F.L., 2015. Microbiological aspects of biodiesel and biodiesel/diese blends biodeterioration. Int. Biodeterior. Biodegrad. 99, 102-114.

[40] Souza, G.K., Scheufele, F.B., Pasa, T.L.B., Arroyo, P.A., Pereira, N.C., 2016. Synthesis of ethyl esters from crude macauba oil (Acrocomia aculeata) for biodiesel production. Fuel. 165, 360-366.

[41] Souza, V.H.A., Dos Santos, L.T., Campos, A.F., Carolino, J., 2015. Análise do Programa Nacional de Produção e Uso do Biodiesel (PNPB): Resultados e Críticas. Rev. Adm. Geral. 1(1), 23-41.

[42] Teixeira, G.A.A., Queiroz, N., Souza, A. L., Garcia, I. M., Maia, A. S., Souza, A. G., 2010. Avaliação dos parâmetros de qualidade para o biodiesel metílico obtido de misturas de óleos vegetais e gordura animal durante armazenamento. Resumos do $4^{\circ}$ Congresso da Rede Brasileira de Tecnologia de Biodiesel, Belo Horizonte, Brasil. 3, 1287-1288.

[43] Tiwari, A.K., Kumar, A., Raheman, H., 2007. Biodiesel production from Jatropha oil (Jatropha curcas) with high free fatty acids: an optimized process. Biomass bioenergy. 31(8), 569-575.

[44] Vieira, T.M., Silva, E. P., Antoniosi Filho, N. R., Vieira, J. D. G. 2006. Determinação e quantificação da degradação bacteriana de biodiesel de óleo de palma. Resumos do $1^{\circ}$ Congresso da Rede Brasileira de Tecnologia do Biodiesel, Brasília, Brasil. 218-223.

[45] Yaakob, Z., Narayanan, B.N., Padikkaparambil, S., 2006. A review on the oxidation stability of biodiesel. Renew. Sust. Energy Rev. 35 $136-153$. 